\title{
QUEEN'S
UNIVERSITY
BELFAST
}

\section{Outgroup prosocial giving during childhood: The role of ingroup preference and outgroup attitudes in a divided society}

Shamoa Nir, L., Razpurker Apfeld, I., Dautel, J. B., \& Taylor, L. (2020). Outgroup prosocial giving during childhood: The role of ingroup preference and outgroup attitudes in a divided society. INTERNATIONAL JOURNAL OF BEHAVIORAL DEVELOPMENT, 45(4), 337-344. https://doi.org/10.1177/0165025420935619

Published in:

INTERNATIONAL JOURNAL OF BEHAVIORAL DEVELOPMENT

Document Version:

Peer reviewed version

Queen's University Belfast - Research Portal:

Link to publication record in Queen's University Belfast Research Portal

Publisher rights

Copyright 2020 The Authors. This work is made available online in accordance with the publisher's policies. Please refer to any applicable terms of use of the publisher.

\section{General rights}

Copyright for the publications made accessible via the Queen's University Belfast Research Portal is retained by the author(s) and / or other copyright owners and it is a condition of accessing these publications that users recognise and abide by the legal requirements associated with these rights.

Take down policy

The Research Portal is Queen's institutional repository that provides access to Queen's research output. Every effort has been made to ensure that content in the Research Portal does not infringe any person's rights, or applicable UK laws. If you discover content in the Research Portal that you believe breaches copyright or violates any law, please contact openaccess@qub.ac.uk. 
OUTGROUP PROSOCIAL BEHAVIOR 1

Running header: OUTGROUP PROSOCIAL BEHAVIOR

\section{Outgroup prosocial giving during childhood: The role of ingroup preference and outgroup attitudes in a divided society}

Lipaz Shamoa-Nir, Zefat Academic College, lipaznir@zahav.net.il

Irene Razpurker-Apfeld, Zefat Academic College, irenea@013.net.il

Jocelyn B. Dautel, Queen’s University Belfast, Jocelyn.Dautel@qub.ac.uk

Laura K. Taylor, University College Dublin \& Queen’s University Belfast, laura.taylor@ucd.ie

Corresponding author: Lipaz Shamoa-Nir, Department of Behavioral Sciences, Zefat Academic College, 11 Jerusalem St., Safed, 13206, Israel.

Acknowledgements: Our thanks to the many families who participated, to Risa Rylander, the project coordinator for Helping Kids! (helpingkidsqubblog.com), and to the Israeli Social Cognition Laboratory. Financial support was provided by DFEGCRF17-18/Taylor, GCRFGIAA18-19/Taylor and British Psychological Society, Social Psychology Section, Pumppriming and Dissemination Fund Application, and Zefat Academic College internal institutional grants: 76-2018/Razpurker-Apfeld and 77-2018/Shamoa-Nir. 


\title{
Outgroup Prosocial Giving During Childhood: The Role of Ingroup Preference and Outgroup Attitudes in a Divided Society
}

\begin{abstract}
Amid protracted conflict, children are raised in divided contexts which shape the development of their intergroup attitudes and behaviors. Social Identity Development Theory (SIDT) suggests that ingroup preference may contribute to more negative outgroup attitudes and behaviors in middle childhood. In such contexts, ingroup favoritism may shape resource distribution, a key indicator of prosocial behavior. This study examined the predictors of resource distribution among 387 children (age: $M=9.59, S D=2.34$ ) of majority (Jewish) and minority (Arab-Muslim) groups in Israel. Rooted in SIDT, a multiple-group chain mediation found that the effect of age on outgroup prosocial giving was serially mediated by the child's ingroup symbol preference and negative outgroup attitudes. The mediation held across both majority and minority groups, highlighting the underlying developmental process of prosocial giving across group lines in a divided society.
\end{abstract}

Keywords: outgroup prosocial behavior, intergroup conflict, resource distribution, children, Israel 
Children's prosocial behaviors may be an antecedent of peacebuilding in historically conflicted societies (Taylor et al., 2014; Taylor, O’Driscoll, Dautel, \& McKeown, 2019). Yet, experimental studies demonstrate that young children are selective about with whom, and when, they engage in prosocial behavior depending on characteristics of the recipient and the situation (for a review see Martin \& Olson, 2015). For instance, children are more likely to engage in prosocial behavior when the recipient is more familiar (Young, Fox, \& Zahn-Waxler, 1999), has previously been kind or helpful to them or others (Dunfield \& Kuhlmeier, 2010), or is a member of their ingroup (Dunham, Baron, \& Carey, 2011). Thus, understanding the mechanisms underlying prosociality is especially important in children with a history of exposure to intergroup conflict and zero-sum political narratives in their day-to-day experiences (e.g. BarTal, 2007), as can be the case in divided societies such as Israel.

The current study models the predictors of outgroup prosocial giving in two ethnic groups in Israel. Rooted in Social Identity Developmental Theory (SIDT; Nesdale, 2004), we examined whether, with age, ingroup preference would relate to negative outgroup attitudes, and if those attitudes would influence prosocial giving based on group membership. Moreover, examining children from Jewish and Arab-Muslim backgrounds in this context of protracted conflict will shed light on whether the same process predicts prosocial giving for members of both majority and minority groups. Understanding factors that promote positive behaviors across group lines among children may inform peacebuilding initiatives within Israel and other historically divided societies (O’Driscoll, Taylor, \& Dautel, 2018; Taylor et al., 2014).

\section{Development of Intergroup Attitudes}

Children attend to social category distinctions from infancy and use social information to navigate their social worlds. By the age of four, children identify outgroup individuals and 
display social preferences based on ethnicity (e.g. Aboud, 1988; Nesdale, 2001). However, ethnic awareness and preferences for ingroup members do not necessarily develop into negative outgroup attitudes (Nesdale, 2004).

SIDT suggests a developmental pathway, taking into account environmental influences, by which children's social categorization and ingroup preferences may develop into outgroup prejudice in attitudes and actions. SIDT outlines four phases: (1) undifferentiated (before 3 years) - ethnic group membership is not yet salient; (2) ethnic awareness (at about 3 years) awareness of ethnic cues emerges; (3) ethnic preference (at about 4 years) - preference of ingroup over outgroup appears; and (4) ethnic prejudice (at about 7 years) - sometimes negative attitudes about the outgroup may emerge (Nesdale, 2004). Prejudice may develop when children not only identify with their ingroup, but also when negative attitudes toward an outgroup are a social norm, or when children observe tense intergroup relations or perceive threats to group status (Nesdale, Maass, Durkin, \& Griffiths, 2005). Under such conditions, negative outgroup attitudes may continue into late childhood (Nesdale, Griffith, Durkin, \& Maass, 2005). This may be the case in Israel, where young children absorb conflict-supporting contents which may persist even later in life (Nasie, Diamond, \& Bar-Tal, 2016).

In Israel, the ethno-religious categories "Jew" and "Arab" describe an extremely salient social dichotomy in the society due to historical and political reasons. The dichotomy also reflects socio-economic gaps in status of the Jewish majority and the Arab minority, where the latter has, on average, lower education, employment, and wages. Consistent with SIDT, children in this region demonstrate awareness of ethnic categories at a young age, as early as age three (Bar-Tal, 1996); they also demonstrate negative stereotyping of outgroup ethnic members (Slone, Tarrasch, \& Hallis, 2000). 
OUTGROUP PROSOCIAL BEHAVIOR 5

The current study builds on the limited research that has explicitly examined intergroup relations during childhood for both minority and majority groups in conflict-affected settings. Although differences have been found between minority and majority group members in terms of felt security (Taylor, Merrilees, Ajduković, Čorkalo Biruški, \& Cummings, 2017), intentions to discriminate (Ajduković \& Čorkalo Biruški, 2008), and ethnic socialization within the family (Štambuk et al., 2019), children's intergroup attitudes have been insufficiently explored in such contexts. Exposure to ingroup symbols, however, has been found to differently affect outgroup attitudes as a function of majority/minority group affiliation for adults (Razpurker-Apfeld \& Shamoa-Nir, 2015; Shamoa-Nir \& Razpurker-Apfeld, 2019a, 2019b). Although Nesdale (1999) suggested that majority group children may show stronger ingroup preference compared to minority group children, SIDT does not specify if the link from ingroup preference to outgroup prejudice might unfold differently for minority and majority children. Therefore, we explore the role of outgroup attitudes in the link from preference to prejudice for minority and majority groups in Israel. Moreover, complementing the focus of previous research largely on discrimination, we focus on intergroup prosocial behaviors.

\section{Development of Prosocial Giving}

Children have a basic motivation to be prosocial (Hay, 1994), and value equality and fairness (Tomasello \& Vaish, 2013). However, children also display selectivity in prosociality (Dunfield \& Kuhlmeier, 2010) and may distribute resources strategically in favor of their ingroup in order to improve their group's position or solidify links with group members (Fehr, Bernhard, \& Rockenbach, 2008). Although increasingly able to weigh both egalitarian concerns and group dynamics in their resource allocation decisions with age (Rutland \& Killen, 2017), 
children still tend to give more resources to ingroup members when an egalitarian response is unavailable or when facing competitive intergroup dynamics (O’Driscoll et al., 2018).

While each of these factors can be present in settings of protracted conflict, the literature linking SIDT processes, such as ingroup preferences and outgroup attitudes, to children's prosocial giving has rarely been studied in these environments. Of the few studies that have explored this relationship between outgroup attitudes and helping intentions, the results have been mixed. Sometimes more negative attitudes about ethnic outgroups are associated with more prosocial intentions and behaviors (e.g., Sierksma, Lansu, Karremans, \& Bijlstra, 2018).

Sometimes more positive attitudes about an outgroup are related to helping intentions of majority children toward an immigrant (Vezzali, Cadamuro, Versari, Giovannini, \& Trifiletti, 2015), but not actual prosocial giving (Taylor \& Glen, 2019). Among adolescents, a positive cross-lagged relationship from outgroup attitudes and outgroup prosocial behavior was found in Northern Ireland, a society of protracted conflict (Taylor et al., 2014). At times, children's outgroup attitudes do not correlate with their prosocial intentions or behaviors toward the outgroup (Renno \& Shutts, 2015). These discrepancies in findings lie in the diversity in children's ages, type of prosocial task and whether the children are raised in a setting of intergroup conflict. The current study expands on past research to explore relations among ingroup preferences, outgroup attitudes, and resource distribution as a prosocial behavior in a context of intergroup conflict.

\section{Current Study}

This study examined how age relates to children's preference for ingroup social, religious, and cultural symbols, and the implications of that preference for intergroup attitudes and actions. Rooted in SIDT and studies in contexts of intergroup conflict (O'Driscoll et al., 2018; Tomovska, Taylor, Dautel, \& Rylander, 2019), we hypothesized that age would relate to 
greater preference for ingroup symbols (e.g., language, clothing, activities). Due to salience and importance of social categories in Israel, we hypothesized that this ingroup preference would link to more negative outgroup attitudes, and those attitudes would influence outgroup prosocial giving (O’Driscoll et al., 2018; Taylor et al., 2019a). Although generally children become less inclined to express explicit outgroup prejudice during late childhood (for a meta-analysis see, Raabe \& Beelmann, 2011), ingroup preference (i.e., bias) has been shown to increase with age in a setting of protracted conflict (e.g., Merrilees et al., 2018). Therefore, we hypothesized that ingroup preference and negative outgroup attitudes would mediate the link from child age to intergroup prosocial behaviors during middle and late childhood. Given the context of social divide, we also examined whether this pattern of results would unfold similarly for children from majority and minority groups.

\section{Method}

\section{Participants}

The age range selected captured the potential shift in SIDT from ethnic preference, phase 3, to ethnic prejudice, phase 4. Power analyses indicated that a total sample size of 190 children would provide a power of .95 in testing hypotheses in our hypothesized model. Using WhatsApp community groups and Facebook in a region in northern Israel, we recruited 387 children: 180 Jewish (105 girls, 75 boys; $M=9.87, S D=2.48,97 \%$ 6-13 years old) and 207 Arab-Muslim (115 girls, 92 boys; $M=9.35, S D=2.19,95 \%$ 6-13 years old). Most of the children (99\% Jewish, $99 \%$ Arab-Muslim) attended homogeneous educational systems and lived in their own respective communities. We received written parental consent and child assent. This study was approved by the institutional ethics committee (ZAC \#401-2018).

\section{Procedure}


Trained researchers worked with children one-on-one in the child's home, with at least one parent in a nearby room. Research assistants of the same ethno-religious group as the child conducted the study in the child's mother tongue. Researchers administered tasks on laptops via Qualtrics by reading the on-screen text; children verbalized or pointed to their answer. Testing sessions lasted about 15 minutes and all children were given a small prize and certificate of participation. The data in this short report was part of a larger cross-cultural study that included other measures. The three tasks were always presented in the same order: ingroup symbol preference, prosocial giving and outgroup attitudes. After the preference task there was a short pause, during which children picked a sticker as an incentive.

\section{Materials and Design}

Ingroup symbol preference. A variety of symbols were pre-tested with adults; those rated as strongly representing either the Arab-Muslim background or the Jewish background were included. Thus, materials included 42 images of symbols (21 pairs; one associated with each ethno-religious background) which represented different aspects of social, cultural, and religious life (e.g., traditions, religious symbols, sports; see examples in Appendix 1; adapted from Tomovska et al., 2019). Each child was presented with a random subset of 10 pairs in a randomized order. The researcher presented and labeled each of two symbols (e.g., "These are Arabic letters. These are Hebrew letters"), and asked children which they liked better. If the child chose an ingroup symbol (e.g., Arab child chose Arabic letters), the item was coded 1; if the child chose an outgroup symbol (e.g., Arab child chose Hebrew letters), the item was coded 0. Higher scores indicated greater ingroup symbol preference.

Outgroup prosocial giving. Adapted from previous work in a divided society (O'Driscoll et al., 2018), children were presented with two gender-matched cartoon stick figures wearing 
OUTGROUP PROSOCIAL BEHAVIOR 9

white t-shirts, one with a Jewish symbol and one with a Muslim symbol. Each figure was labelled with the respective religious label and a name, for example, "This girl is Muslim. Her name is Fatma." The side of the screen each figure was presented on was randomized across children. The researcher explained that there were seven extra stickers leftover to give away to these children in Israel. Children were explicitly told that as long as all stickers were shared they could distribute the stickers in any way (e.g., all to one person or shared between), and that there was no right or wrong answers. Children dragged the stickers to their chosen figure on screen. The number of stickers given to either child could range from zero to seven. For this variable, the number of stickers given to the outgroup member was recorded, with higher scores indicating greater outgroup prosocial giving. This measure reveals an outgroup/ingroup bias in prosocial sharing.

Negative outgroup attitudes. Children were presented with four cartoon stick figures (two male, two female) wearing white t-shirts with a symbol of the participant's ethnic outgroup, and labelled as members of the outgroup with a category label and ethnically stereotypical names (e.g., a Muslim participant would view Jewish children wearing the Star of David named Rutie, Hila, Daniel, and Avi). Children were then asked how much they (1) like the outgroup children, (2) trust the outgroup children, and (3) want to play with the outgroup children (adapted from Nesdale, Milliner, Duffy, \& Griffiths, 2009). The three questions were presented in random order. Children responded on a 4-point scale thumbs up/down scale ranging from 0 (I like/trust/want to play with them a lot) to 3 (I do not like/trust/want to play with them at all). Scores were totalled, ranging from 0 to $9(\alpha=.90)$, with higher scores indicating more negative outgroup attitudes.

\section{Data Analytic Plan}


The hypothesized models were tested using path analysis in Mplus 6 (Muthén \& Muthén, 1998-2011) with maximum likelihood estimation under the assumption that data are missing at random. Bootstrapped chain mediation with 1,000 replications and a 95\% confidence interval was used to estimate the indirect effects. Manifest variables were used for all constructs, including child's gender and ethnic group. Age was the primary exogenous predictor, with ingroup symbol preference and negative outgroup attitudes entered as sequential mediators; outgroup prosocial giving was modelled as the outcome of interest. Given past research has found gender differences in prosocial behaviors (Eisenberg, Fabes, \& Spinrad, 2006), we also controlled for child gender in the following models (results were largely the same without controlling for gender). Model fit was assessed using the following guidelines: Tucker Lewis Index $(\mathrm{TLI})$ and comparative fit index $(\mathrm{CFI}) \geq .90$, root mean square residual (RMSEA) and standardized root mean square residual $(\mathrm{SRMR}) \leq .08$ (Hu \& Bentler, 1999).

Three nested models were tested. First, the fully constrained model (Model 1) estimated the chain mediation for the entire sample. Second, the fully unconstrained model (Model 2) allowed all paths to be estimated freely for both ethnic groups. Third, to assess if the processes unfolded similarly for both groups of children, a multiple group framework with a step-up approach was used (Model, 3; Brown, 2006). In this procedure, the structural paths are constrained one-by-one across groups and model fit is assessed with a chi-square difference test. In other words, if a path is constrained to be equal across groups and the model fit does not worsen, that constraint is retained, and the next path is tested. This comparative approach yields the most parsimonious model, while allowing for significant group differences. 
OUTGROUP PROSOCIAL BEHAVIOR 11

\section{Results}

Table 1 presents descriptive statistics and bivariate correlations for each group. Given the possible range of zero to seven, the mean of outgroup prosocial giving is low for both groups (see also Appendix 2). Significant correlations include the link from age to ingroup symbol preference for the Arab, and from age to negative outgroup attitudes for the Jewish sample; in both groups, there is a significant negative correlation between negative outgroup attitudes and prosocial giving.

\section{INSERT TABLE 1 HERE}

First, Model 1 tested the chain mediation fully constraining all paths to be equal across Arab-Muslim and Jewish children. The proposed model was a good fit to the data (Model 1: $\left.N=387, \chi^{2}(2)=1.45, p=.49 ; \mathrm{CFI}=1.00 ; \mathrm{TLI}=1.02 ; \mathrm{SRMR}=.013 ; \mathrm{RMSEA}=.000(\mathrm{CI}: .000, .092)\right)$ and there was a significant indirect effect from child age to outgroup prosocial giving, through ingroup symbol preference and negative outgroup attitudes. (b=-.007, 95\%CI: -.014,-.001). Second, Model 2 tested the same chain mediation with a multiple group framework which allowed all structural paths to be estimated separately by group. This fully unconstrained model also had acceptable model fit (Model 2: $N_{\text {Muslim }}=207, \mathrm{~N}_{\text {Jewish }}=180, \chi^{2}(4)=4.99, p=.22 ; \mathrm{CFI}=.99$; TLI=.96; SRMR=.027; RMSEA=.036 (CI: .000 .119)) and a significant indirect effect for ArabMuslims (b=-.018, 95\%CI: -.047,-.000), but not for Jews (b=-.004, 95\%CI: -.029,.003).

Third, the step-up approach was applied to Model 2. The chi-square difference tests compared nested models, as each structural path was constrained to be equal across groups to examine if there are differences in how the process unfolds for majority and minority groups. In the final model (Model 3), all structural paths, including the control variable of gender, were constrained, except for the path from negative outgroup attitudes to outgroup prosocial behavior. 
That is, when this path was constrained to be equal, there was worse model fit. Therefore, this path was estimated separately for each group, and was stronger for Jewish $(\beta=-0.55, p<.001)$ children compared to Arab-Muslims $(\beta=-0.41, p<.001)$. The indirect effects for both groups (Arab-Muslim: b=-.009, 95\%CI: -.024,-.001; Jewish: b=-.013, 95\%CI: -.033,-.001) were significant in the final step-up model, which was a good fit to the data (Model 3: $N_{\text {Muslim }}=207$, $\mathrm{N}_{\text {Jewish }}=180, \chi^{2}(10)=10.96, p=.36 ; \mathrm{CFI}=.99 ; \mathrm{TLI}=.99 ; \mathrm{SRMR}=.047 ; \mathrm{RMSEA}=.022$ (CI: .000, .083)). Moreover, Model 3 was a significantly better fit to the data that Models 1 or 2, and explained $18 \%$ and $30 \%$ of the variance in tendency to discriminate for Arab-Muslims and Jews, respectively.

Figure 1 depicts the direct and indirect structural paths for Model 3. For both groups, age was positively related to ingroup symbol preference, which was related to more negative outgroup attitudes. Lower negative outgroup attitudes, however, were linked with greater outgroup prosocial giving (i.e., a reduced sharing bias against the outgroup was observed). The remaining direct effects from child age and gender to outgroup prosocial giving were nonsignificant. Thus, there was support for the hypothesized chain mediation model; with age, children's preferences and attitudes change, which influences their bias in outgroup giving.

\section{INSERT FIGURE 1 HERE}

\section{Discussion}

This study extends previous research on how group processes influence children's social exclusion and resource-allocation decisions (Killen, Elenbaas, Rizzo, \& Rutland, 2017), in particular in groups with longstanding histories of conflict (O’Driscoll et al., 2018). Framed by SIDT (Nesdale, 2004), the current study examined whether ingroup symbol preference affects outgroup attitudes and willingness to give them resources. For both Jewish majority and Arab- 
Muslim minority children in Israel, the effect of age on outgroup prosocial giving was serially mediated by the child's ingroup symbol preference and negative outgroup attitudes. Consistent with previous research which found ingroup prosocial favoritism by five years old (Dunham et al., 2011; Rutland, Hitti, Mulvey, Abrams, \& Killen, 2015), this effect is persistent across middle childhood in the current study. The multiple group analyses only revealed a difference in one path: for Jewish majority children, there was a stronger association between negative outgroup attitudes to outgroup prosocial giving, compared to Arab-Muslim minority children. As in other contexts of risk (O'Driscoll et al., 2018), the findings suggest that group processes may shape the development of prosocial giving (McGuire, Manstead, \& Rutland, 2017).

The present research was conducted in a social context characterized by risk related to social division and intergroup tension. Factors such as ethnic identification and group status may shape ingroup favouritism (Verkuyten, 2007), leading eventually to prosocial behaviour in favour of a child from one's ingroup over a child from the outgroup (O'Driscoll et al., 2018). Examining this process across both majority and minority groups is essential in such settings (Adjukovic \& Corkalo Biruski, 2008). For example, there are socio-economic gaps in the status of the Jewish majority and the Arab minority, where the latter has a larger family size and lower education, employment, and wages. Indeed, while minority group members can be expected to relate to their unique ethnic identification (Liebkind, 1989), at the same time, the lower status of minority group members may prevent them from positively differentiating their group from the majority (Ellemers, Van Rijswijk, Roefs, \& Simons, 1997). This partial lack of differentiation may explain why the minority in this study demonstrated a weaker relationship between negative outgroup attitudes and prosocial outgroup giving compared with the majority. Yet, despite this difference, the overall mediation was the same for both groups. This is consistent with a previous 
OUTGROUP PROSOCIAL BEHAVIOR 14

study with majority Dutch and minority Turkish children ages 10 to 12 that demonstrated similar effects of ingroup favouritism on feelings of self-worth (Verkuyten, 2007). This finding suggests that SIDT may be capturing an underlying developmental process in a divided society.

\section{Limitations and Future Research}

Despite the study's strengths, such as including both majority and minority perspectives in the same model, there are a number of limitations that could be addressed in future research. First, the order of the tasks in this study was not counterbalanced, so the results may have been influenced by order effects. Second, despite the direction of effects in the current model being based on theory, the study tests mediation with cross-sectional data, which may bias estimates (Maxwell \& Cole, 2007); testing alternative directions, or 'reversing the arrows', with the current design is not advised (Thoemmes, 2015). Therefore, future research should employ an experimental approach to investigate causation or a longitudinal design to make inferences about the direction of effects. Third, given the context of social division, future research could explore if children's perception of the broader conflict or intergroup tension (Taylor et al., 2019b) and their intergroup contact have an effect on the model (McKeown \& Taylor, 2017). Fourth, the current study was conducted in a relatively stable environment in terms of conflict. Future research should focus on the most intense conflict in this region examining Jewish Israelis and Arab-Palestinian societies (e.g., Gaza, the West Bank, East Jerusalem). Finally, recent research has found that compared to Arab-Christians, Arab-Muslims expressed more negative stereotypes about the Jewish majority (Shamoa-Nir \& Razpurker-Apfeld, 2019a). Therefore, replication of this study among other minorities living in Israel such as Arab-Christians or Druze should be considered.

\section{Implications for Practice and Policy}


The current findings indicate that children favour the ingroup over the outgroup when sharing resources. The findings also show outgroup attitudes predict outgroup sharing bias. This contrasts with previous research showing that attitudes did not relate to intergroup prosociality (Renno \& Shutts, 2015), suggesting that social context may play a crucial role in this relation. The existence of an ongoing intergroup conflict in Israel may have shaped the link from negative attitudes to sharing bias. This idea is reinforced by Bauer and colleagues (2014) who found that exposure to war increased both children's ingroup favouritism and outgroup derogation.

Practically speaking, our findings may help promote prosocial behaviour. Sharing resources with a former rival is essential to building a shared future. Therefore, identifying the processes relating to greater outgroup giving and less bias against them has implications for programs aiming to improve intergroup relations. For example, conducting interventions targeting early attitudes may help to reduce bias in prosocial giving. Indeed, programs in elementary Israeli schools that emphasized social-emotional learning have shown to decrease outgroup prejudice and discrimination (Berger, Benatov, Abu-Raiya, \& Tadmor, 2016). In addition, these findings may have longer-term implications for policy; that is, in conflict settings, a zero-sum mindset often prevents collaboration and cooperation. Understanding how to promote resource distribution across group lines, even among children, may not only help to improve relations between Jews and Arabs who live in Israel, but potentially, future peacebuilding initiatives between Israel and the Palestinians.

In conclusion, this paper contributes to understanding the development of prosocial behaviors across group lines in a setting of protracted conflict. Despite differences in group status, the overall chain mediation rooted in SIDT held for both Jewish and Arab-Muslim children. Fitting in the growing body of work at the interface of social and developmental 
psychology (Killen et al., 2017), this paper extends the implications to peace psychology, lending insight to how prosocial giving might be further encouraged for later peacebuilding potential (McKeown \& Taylor, 2017). 


\section{References}

Aboud, F.E. (1988). Children and Prejudice. Oxford, UK: Blackwell's.

Ajduković, D. \& Čorkalo Biruški, D. (2008). Caught between the ethnic sides: Children growing up in a divided post-war community. International Journal of Behavioral Development, 32(4), 337-347. https://doi.org/10.1177/0165025408090975

Bar-Tal, D. (1996). Development of social categories and stereotypes in early childhood: The case of "the Arab" concept formation, stereotype, and attitudes by Jewish children. International Journal of Intercultural Relations, 20(3-4), 341-370. https://doi.org/10.1016/0147-1767(96)00023-5

Bar-Tal, D. (2007). Sociopsychological foundations of intractable conflicts. American Behavioral Scientist, 50(11), 1430-1453. https://doi.org/10.1177/0002764207302462

Bauer, M., Cassar, A., Chytilová, J., \& Henrich, J. (2014). War's enduring effects on the development of egalitarian motivations and in-group biases. Psychological Science, 25(1), 47-57. https://doi.org/10.1177/0956797613493444

Berger, R., Benatov, J., Abu-Raiya, H., \& Tadmor, C.T. (2016). Reducing prejudice and promoting positive intergroup attitudes among elementary-school children in the context of the Israeli-Palestinian conflict. Journal of School Psychology, 57, 53-72. https://doi.org/10.1016/j.jsp.2016.04.003

Brown, T.A. (2006). Confirmatory Factor Analysis for Applied Research. New York, NY, US: Guildford Press.

Dunfield, K.A. \& Kuhlmeier, V.A. (2010). Intention-mediated selective helping in infancy. Psychological Science, 21(4), 523-527. https://doi.org/10.1177/0956797610364119 
Dunham, Y., Baron, A.S., \& Carey, S. (2011). Consequences of "minimal” group affiliations in children. Child Development, 82(3), 793-811. https://doi.org/10.1111/j.1467$\underline{8624.2011 .01577 . x}$

Eisenberg, N., Fabes, R. A., \& Spinrad, T. L. (2006). Handbook of child psychology. John Wiley \& Sons.

Ellemers, N., Van Rijswijk, W., Roefs, M., \& Simons, C. (1997). Bias in intergroup perceptions: Balancing group identity with social reality. Personality and Social Psychology Bulletin, 23(2), 186-198. https://doi.org/10.1177/0146167297232007

Fehr, E., Bernhard, H., \& Rockenbach, B. (2008). Egalitarianism in young children. Nature, 454, 1079-1083. https://doi.org/10.1038/nature07155

Hay, D.F. (1994). Prosocial development. The Journal of Child Psychology and Psychiatry, 35(1), 29-71. https://doi.org/10.1111/j.1469-7610.1994.tb01132.x

Hu, L.T., \& Bentler, P.M. (1999). Cutoff criteria for fit indexes in covariance structure analysis: Conventional criteria versus new alternatives. Structural Equation Modeling: A Multidisciplinary Journal, 6(1), 1-55. https://doi.org/10.1080/10705519909540118

Killen, M., Elenbaas, L., Rizzo, M.T., \& Rutland, A. (2017). The role of group processes in social exclusion and resource allocation decisions. In A. Rutland, D. Nesdale, \& C.S. Brown (Eds.), The Wiley Handbook of Group Processes in Children and Adolescents (pp. 101-123). West Sussex, UK: John Wiley \& Sons Ltd. https://doi.org/10.1002/9781118773123.ch5

Liebkind, K. (1989). The identity of a minority. Journal of Multilingual \& Multicultural Development, 10(1), 47-57. https://doi.org/10.1080/01434632.1989.9994362 
Martin, A. \& Olson, K.R. (2015). Beyond good and evil: What motivations underlie children's prosocial behavior? Perspectives on Psychological Science, 10(2), 159-175. https://doi.org/10.1177/1745691615568998

Maxwell, S.E., \& Cole, D.A. (2007). Bias in cross-sectional analyses of longitudinal mediation. Psychological Methods, 12(1), 23-44. https://doi.org/10.1037/1082-989X.12.1.23

McGuire, L., Manstead, A.S.R., \& Rutland, A. (2017). Group norms, intergroup resource allocation, and social reasoning among children and adolescents. Developmental Psychology, 53(12). 2333-2339. https://doi.org/10.1037/dev0000392

McKeown, S. \& Taylor, L.K. (2017). Intergroup contact and peacebuilding: Promoting youth civic engagement in Northern Ireland. Journal of Social and Political Psychology, 5(2), 415-434. https://doi.org/10.5964/jspp.v5i2.769

Merrilees C.E., Taylor, L.K., Baird, R., Goeke-Morey, M.C., Shirlow, P., \& Cummings E.M. (2018). Neighborhood effects of intergroup contact on change in youth intergroup bias. Journal of Youth and Adolescence, 47(1), 77-87. doi: 10.1007/s10964-017-0684-6

Muthén, L.K., \& Muthén, B.O. (1998-2011). Mplus User's Guide. Seventh Edition. Los Angeles, CA: Muthén \& Muthén.

Nasie, M., Diamond, A. H., \& Bar-Tal, D. (2016). Young children in intractable conflicts: The Israeli case. Personality and Social Psychology Review, 20(4), 365-392. https://doi.org/10.1177/1088868315607800

Nesdale, D. (1999). Social identity and ethnic prejudice in children. In P. Martin, \& W. Noble (Eds.), Psychology and society (pp. 92 - 110). Brisbane7 Australian Academic Press. 
Nesdale, D. (2001). The development of prejudice in children. In M. A. Augoustinos \& K. J. Reynolds (Eds.) Understanding Prejudice, Racism, and Social conflict (pp. 57-73). London: Sage. https://doi.org/10.4135/9781446218877.n4

Nesdale, D. (2004). Social identity processes and children's ethnic prejudice. In M. Bennett \& F.S. Sani (Eds.), The Development of the Social Self (pp. 219-245). New York, NY, US: Psychology Press. https://doi.org/10.4324/9780203391099_chapter_8

Nesdale, D., Griffith, J., Durkin, K., \& Maass, A. (2005). Empathy, group norms and children's ethnic attitudes. Journal of Applied Developmental Psychology, 26(6), 623-637. https://doi.org/10.1016/j.appdev.2005.08.003

Nesdale, D., Maass, A., Durkin, K., \& Griffiths, J.A. (2005). Group norms, threat, and children's racial prejudice. Child Development, 76(3), 652-663. https://doi.org/10.1111/j.14678624.2005.00869.x

Nesdale, D., Milliner, E., Duffy, A., \& Griffiths, J.A. (2009). Group membership, group norms, empathy, and young children's intentions to aggress. Aggressive Behavior, 35(3), 244258. https://doi.org/10.1002/ab.20303

O’Driscoll, D., Taylor, L.K., \& Dautel, J. (2018). Intergroup resource distribution among children living in segregated neighborhoods amid protracted conflict. Peace and Conflict: Journal of Peace Psychology, 24(4), 464-474. https://doi.org/10.1037/pac0000348

Raabe, T., \& Beelmann, A. (2011). Development of ethnic, racial, and national prejudice in childhood and adolescence: A multinational meta-analysis of age differences. Child development, 82(6), 1715-1737. https://doi.org/10.1111/j.1467-8624.2011.01668.x 
OUTGROUP PROSOCIAL BEHAVIOR 21

Razpurker-Apfeld, I., \& Shamoa-Nir, L. (2015). The influence of exposure to religious symbols on out-group stereotypes. Psychology, 6(05), 650-663. https://doi.org/10.4236/ psych.2015.65063

Reidy, C.M., Taylor, L.K., Merrilees, C.E., Ajduković, D., Čorkalo Biruški, D., Cummings, E.M. (2015). The political socialization of youth in a post-conflict community. International Journal of Intercultural Relations, 45, 11-23. doi: 10.1016/j.ijintrel.2014.12.005

Renno, M. P., \& Shutts, K. (2015). Children's social category-based giving and its correlates: Expectations and preferences. Developmental Psychology, 51(4), 533-543. https://doi.org/10.1037/a0038819.

Rutland, A., Hitti, A., Mulvey, K.L., Abrams, D., \& Killen, M. (2015). When Does the In-Group Like the Out-Group? Bias Among Children as a Function of Group Norms. Psychological Science, 26(6), 834-842. https://doi.org/10.1177/0956797615572758

Rutland, A. \& Killen, M. (2017). Fair resource allocation among children and adolescents: The role of group and developmental processes. Child Development Perspectives, 11(1), 56-62. https://doi.org/10.1111/cdep.12211

Shamoa-Nir, L., \& Razpurker-Apfeld, I. (2019a). Investigating stereotypes towards the outgroup: The role of religious concepts and group membership. Basic and Applied Social Psychology, 41(3), 188-200. https://doi.org/10.1080/01973533.2019.1610657

Shamoa-Nir, \& Razpurker-Apfeld, I. (2019b). Religious primes and threat-perceptions as predictors of attitudes toward Muslims in Israel. Integrative Psychological and Behavioral Science. doi: 10.1007/s12124-019-09509-z 
Sierksma, J., Lansu, T. A., Karremans, J. C., \& Bijlstra, G. (2018). Children's helping behavior in an ethnic intergroup context: Evidence for outgroup helping. Developmental Psychology, 54(5), 916-928. https://doi.org/10.1037/dev0000478.

Slone, M., Tarrasch, R., \& Hallis, D. (2000). Ethnic stereotypic attitudes among Israeli children: Two intervention programs. Merrill-Palmer Quarterly, 46(2), 370-389.

Štambuk, M., Taylor, L.K., Löw, A., Čorkalo Biruški, D., Merrilees, C. E., Ajduković, D., \& Cummings, E. M. (2019). Parental competitive victimhood and interethnic discrimination among their children: The mediating role of ethnic socialization and symbolic threat to the in-group. British Journal of Social Psychology. doi.org/10.1111/bjso.12321

Taylor, L.K., \& Glen, C. (2019). From empathy to action: Can enhancing host-society children's empathy promote positive attitudes and prosocial behavior towards refugees? Journal of Community and Applied Social Psychology. https://doi.org/10.1002/casp.2438

Taylor, L.K., Merrilees, C.E., Goeke-Morey, M.C., Shirlow, P., Cairns, E., \& Cummings, E.M. (2014). Political violence and adolescent outgroup attitudes and prosocial behaviors: Implications for positive intergroup relations. Social Development, 23(4), 840-859. https://doi.org/10.1111/sode.12074

Taylor, L.K., Merrilees, C.E., Ajduković, D., Čorkalo Biruški, D., Cummings, E.M. (2017). Complexity of risk: Mixed methods approach to understanding risk and insecurity in post-conflict settings. Journal of Adolescent Research, 32(5), 585-613.doi:

\section{$\underline{10.1177 / 0743558416684950}$}

Taylor, L.K., O’Driscoll, D., Dautel, J., \& McKeown, S. (2019a). Empathy to action: Child and adolescent outgroup attitudes and prosocial behaviors in a setting of intergroup conflict. Social Development. $\underline{\text { doi.org/10.1111/sode.12421 }}$ 
Taylor, L.K., Townsend, D., Merrilees, C.E., Goeke-Morey, M.C., Shirlow, P., \& Cummings, E.M. (2019b). Adolescent civic engagement and perceived political conflict: The role of family cohesion. Youth \& Society, 51(5), 616-637. https://doi.org/10.1177/0044118X17697236

Thoemmes, F. (2015). Reversing Arrows in Mediation Models Does Not Distinguish Plausible Models. Basic and Applied Social Psychology, 37(4), 226234. doi: 10.1080/01973533.2015.1049351

Tomasello, M. \& Vaish, A. (2013). Origins of human cooperation and morality. Annual Review of Psychology, 64, 231-255. https://doi.org/10.1146/annurev-psych-113011-143812

Tomovska Misoska, A., Taylor, L.K., Dautel, J., \& Rylander, R. (2019). Children’s understanding of ethnic group symbols: Piloting an instrument in the Republic of North Macedonia. Peace \& Conflict: Journal of Peace Psychology.

Verkuyten, M. (2007). Social psychology and multiculturalism. Social and Personality Psychology Compass, 1(1), 280-297. https://doi.org/10.1111/j.1751-9004.2007.00011.x Vezzali, L., Cadamuro, A., Versari, A., Giovannini, D., \& Trifiletti, E. (2015). Feeling like a group after a natural disaster: Common ingroup identity and relations with outgroup victims among majority and minority young children. The British Journal of Social Psychology, 54, 519-538. https://doi.org/10.1111/bjso.12091

Young, S.K., Fox, N.A., \& Zahn-Waxler, C. (1999). The relations between temperament and empathy in 2-year-olds. Developmental Psychology, 35(5), 1189-1197. https://doi.org/10.1037/0012-1649.35.5.1189 
OUTGROUP PROSOCIAL BEHAVIOR 24

\section{Table 1}

Means, standard deviations and bivariate correlations for all study variables $(N=387)$

\begin{tabular}{|c|c|c|c|c|c|c|c|c|c|c|c|c|c|c|c|}
\hline & & \multicolumn{7}{|c|}{ Arab-Muslim $(n=207)$} & \multicolumn{7}{|c|}{ Jewish $(n=180)$} \\
\hline & & $M$ & $S D$ & 1 & 2 & 3 & 4 & 5 & $M$ & $S D$ & 1 & 2 & 3 & 4 & 5 \\
\hline & Female & \multicolumn{2}{|c|}{$\begin{array}{c}44 \% \text { male, } 56 \% \\
\text { female }\end{array}$} & \multirow[t]{2}{*}{-} & .08 & .10 & .06 & .04 & \multicolumn{2}{|c|}{$\begin{array}{l}42 \% \text { male, } 58 \% \\
\text { female }\end{array}$} & - & .07 & .04 & -.14 & .14 \\
\hline 2 & Age & 6.39 & 2.16 & & - & $.25^{* * *}$ & -.05 & -.09 & 6.87 & 2.47 & & - & .10 & $-0.24 * *$ & .05 \\
\hline 3 & Ingroup Symbol Preference & 7.73 & 1.44 & & & - & .12 & -.07 & 8.02 & 1.37 & & & - & .038 & -.02 \\
\hline 4 & Negative Outgroup Attitudes & 5.33 & 2.86 & & & & - & $-.40^{* * *}$ & 6.27 & 2.50 & & & & - & $-.54^{* * * *}$ \\
\hline 5 & Outgroup Prosocial Giving & 1.81 & 1.35 & & & & & & 1.81 & 1.37 & & & & & - \\
\hline
\end{tabular}

Note: $* p<.05, * * p<.01, * * * p<.001$ 
Figure 1

Chain mediation path model (Model 3) demonstrating the indirect effect of child age on outgroup prosocial giving through ingroup preference and negative outgroup attitudes for Arab-Muslim and Jewish children in Israel.

Note. Control variable of gender is not depicted for readability. Indirect effects are depicted with dotted lines. Standardized regression coefficients are reported, unless otherwise noted. Structural coefficients were constrained to be equal across groups, therefore, there is only one estimate; the exception is the structural path from negative outgroup attitudes on outgroup prosocial giving which is different for Jews (in bold) and Arab-Muslims (in italics). ${ }^{*} p<.05 ; * * p<.01 ; * * * p<$ .001 .

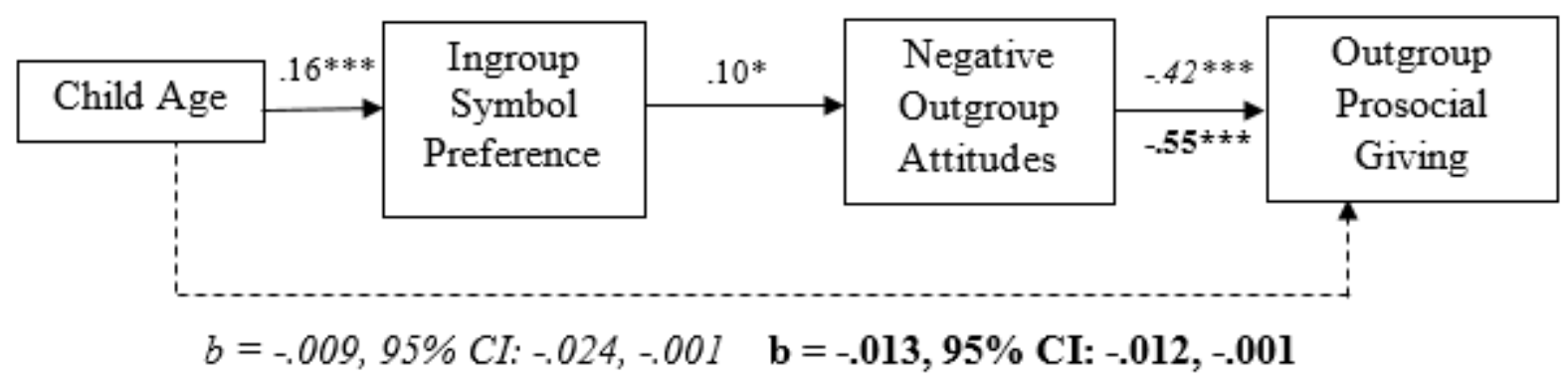




\section{Appendix 1}

Example Symbol Pairs

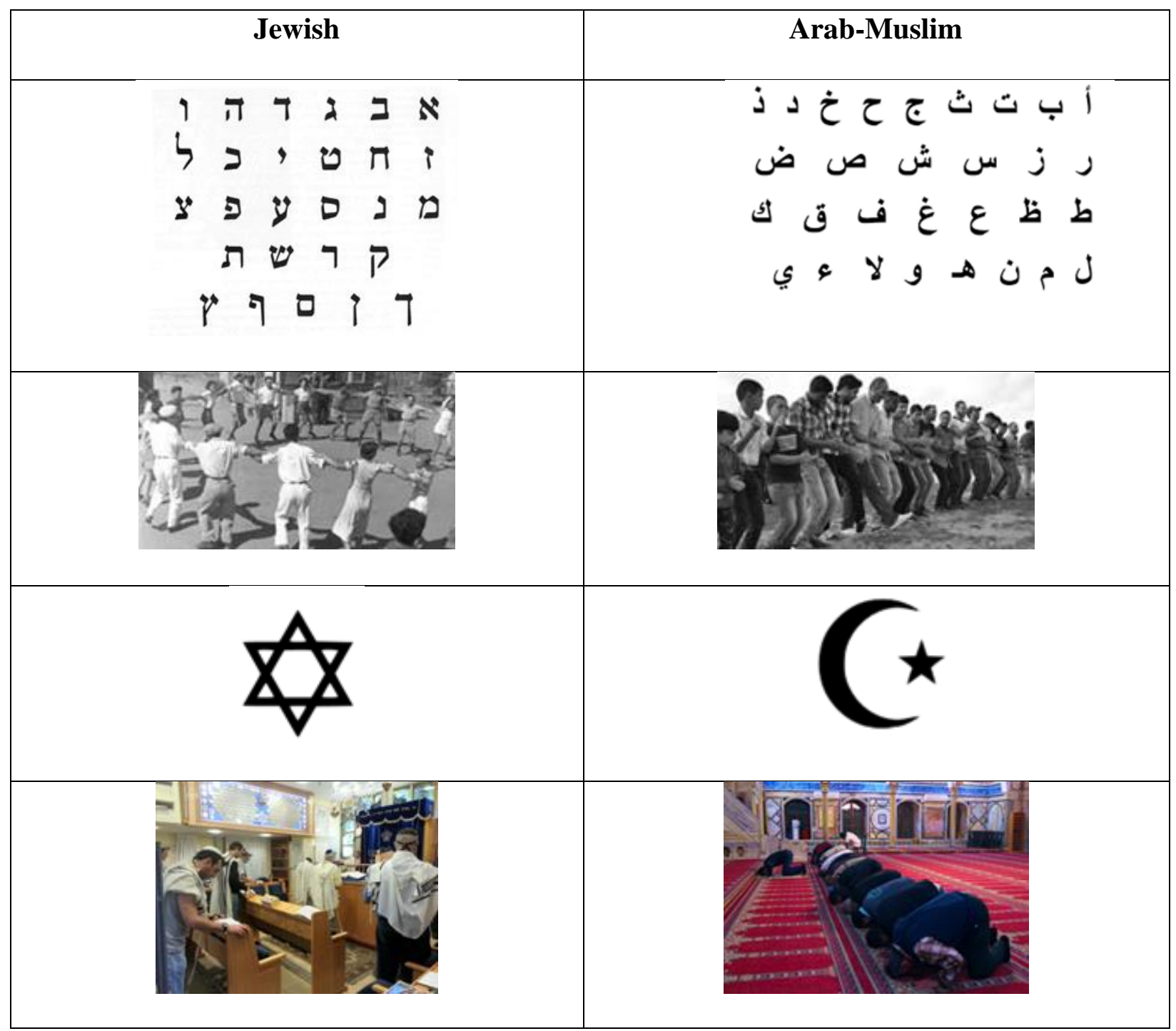


OUTGROUP PROSOCIAL BEHAVIOR 27

\section{Appendix 2}

Outgroup Prosocial Giving: Outgroup Sticker Distribution by Arab-Muslim and Jewish Children

\begin{tabular}{c|c|c}
\hline $\begin{array}{c}\text { Number of Stickers } \\
\text { Distributed to the Outgroup }\end{array}$ & $\begin{array}{c}\text { Percentage of Arab-Muslim } \\
(\mathrm{n}=207)\end{array}$ & $\begin{array}{c}\text { Percentage of Jewish } \\
(\mathrm{n}=180)\end{array}$ \\
\hline 0 & 25.1 & 28.9 \\
2 & 16.4 & 12.8 \\
3 & 18.4 & 11.7 \\
4 & 32.9 & 41.7 \\
5 & 6.3 & 5.0 \\
6 & 1.0 & 0 \\
7 & 0 & 0 \\
\hline
\end{tabular}

Note: All seven stickers had to be distributed between outgroup and/or ingroup. Therefore, $0 \%$ of 7 stickers distributed to the outgroup, means that all 7 stickers were distributed to the ingroup. 